\title{
SISTEM INFORMASI MANAJEMEN AKTIVITAS HARIAN PROYEK BERBASIS WEB PADA PT. SISCOM TECHNOLOGIES TANGERANG SELATAN
}

\author{
Ependi $^{1}$ \\ ${ }^{1}$ Program Studi Manajemen \\ Universitas Mohammad Husni Thamrin \\ ependi71@yahoo.com
}

\author{
Farhan $^{2}$ \\ ${ }^{2}$ Program Studi Teknik Informatika \\ Universitas Mohammad Husni Thamrin
}

\begin{abstract}
Information is a very important need for humans. The rapid development of technology makes it easier for anyone to obtain information quickly and accurately. For PT. Siscom Technologies which is engaged in services, information is needed to control the daily activities of project implementation.

This system aims to make it easier for users or employees to send their daily reports after carrying out activities in the project. In this system, employees only need to fill in a form of data that has been provided. This system also makes it easier for the Director to see the work results or daily progress of a project that is being worked on by an employee by selecting which project the report will see. The Management Information System will show the progress of a project. With the system these data or reports that have been received are neatly arranged, because incoming data or reports are already based on the project being undertaken and will not be mixed up by other reports. Tools for system development are XAMPP, especially PHP. While the system design uses the concept of Unified Modeling Language (UML).
\end{abstract}

Keywords: Management Information Systems, Web Applications, Project Daily Activities

\footnotetext{
Abstrak- Informasi merupakan kebutuhan yang sangat penting bagi manusia. Perkembangan teknologi yang semakin pesat memudahkan siapa saja untuk memperoleh informasi secara cepat dan akurat. Bagi PT. Siscom Technologies yang bergerak di bidang jasa, informasi sangat dibutuhkan untuk mengontrol aktivitas harian dari pelaksanaan proyek.

Sistem ini bertujuan untuk mempermudah para pengguna atau karyawan dalam mengirimkan laporan harian mereka setelah melakukan kegiatan di proyek. Dalam sistem ini karyawan hanya perlu mengisi sebuah data yang berbentuk form yang sudah disediakan. Sistem ini juga mempermudah Direktur untuk melihat hasil kerja atau progress harian dari sebuah proyek yang sedang dikerjakan oleh karyawan dengan memilih proyek mana yang akan dilihat laporannya. Sistem Informasi Manajemen dapat akan memperlihatkan progress suatu proyek. Dengan sistem ini data-data atau laporan yang sudah diterima tersusun dengan rapi, karena data-data atau laporan yang masuk sudah
}

berdasarkan proyek yang dikerjakan dan tidak akan tercampur oleh laporan-laporan yang lain. Alat untuk pengembangan sistem adalah XAMPP khususnya PHP. Sedangkan perancangan sistem menggunakan konsep Unified Modeling Language(UML).

Kata Kunci: Sistem Informasi Manajemen, Aplikasi Web, Aktivitas Harian Proyek

\section{PENDAHULUAN}

PT. Siscom Technologies (dikenal sebagai Siscomtech), didirikan untuk menyediakan layanan Infrastruktur Telekomunikasi, Teknologi Informasi dan Multimedia. Siscomtech didirikan pada tahun 2006 oleh dua orang yang mempunyai keahlian di bidang transmisi radio. PT. Siscom Technologies menyediakan layanan terintegrasi untuk konsultasi, perencanaan, pelaksanaan dukungan, manajemen proyek dan peralatan Telekom serta dukungan Manajemen Pemeliharaan. Perusahaan mengembangkan produk dan layanan kebutuhan pelanggan berbasis komitmen penuh, keahlian dan pengalaman di bidang telekomunikasi, infrastruktur seperti sistem BSS, Microwave, Satelit, Fiber Optic, Sistem Transmisi Tembaga dan komunikasi data. Siscomtech memiliki komitmen untuk menyediakan jaringan infrastruktur di bidang telekomunikasi, Informasi Teknologi dan Multimedia dengan solusi yang terpadu.

Prosedur sistem berjalan sebagai berikut: Karyawan membuat rencana kerja terlebih dahulu. Jika rencana kerja yang sebelumnya belum di selesaikan, maka karyawan harus menyelesaikannya sebelum membuat rencana yang baru. Setelah 
membuat rencana kerja atau menyelesaikan yang sudah ada, maka karyawan membuat laporan kerja pada hari tersebut. Setelah itu, karyawan harus melaporkannya atau mengirimkan laporan tersebut ke manajer projek. Manajer projek menerima email dari para karyawan yang bekerja di projek itu. Manajer projek harus melaporkannya kembali ke direktur tentang perkembangan projek tersebut dalam hardcopy. Menejer projek membuat 2 hardcopy sebagai dokumen harian projek. Direktur menerima laporan dari menejer projek dan mamasukannya ke arsip.

Dari sistem yang berjalan saat ini, terdapat beberapa masalah, diantaranya : Laporan yang disampaikan kepada Direktur kurang terartur. Laporan yang dikirim secara bersamaan tidak dengan kategori atau berdasarkan proyek yang dikerjakan. Karyawan tidak terinformasikan tentang berita terakhir suatu projek, dikarenakan kurang adanya komunikasi antar karyawan. Direktur tidak terinfomasikan mengenai kemajuan dari pengerjaan suatu projek . Laporan projek sering hilang dikarenakan dalam pengumpulan laporan masih berbentuk hardcopy.

Dari analisis sistem yang berjalan saat ini, kebutuhan PT Siscom Technologies, diantaranya : Direktur membutuhkan laporan yang akurat mengenai projek yang telah dikerjakan dan progress pengerjaan projek yang masih dalam status pengerjaan. Direktur membutuhkan laporan mengenai apa saja yang sudah dilakukan dalam pengerjaan suatu projek. Karyawan membutuhkan laporan terakhir untuk membuat rencana kerja sebelum melakukan pekerjaan yang belum dikerjakan.

Bertolak dari masalah sistem berjalan saat ini, perlu dibuat sebuah website sebagai solusi permasalahan tersebut. Sistem ini memungkinkan direktur bisa melihat laporan proyek dengan teratur, cukup dengan memilih proyek mana yang akan dilihat laporannya. Karyawan mudah dalam melaporkan proyek berdasarkan proyek yang dikerjakan tiap hari. Tanpa perlu komunikasi antara pegawai, pegawai bisa memilih proyek yang akan dilihat berita terakhirnya.

\section{METODE PENELITIAN}

Untuk membuat Sistem Informasi Manajemen aktivitas harian projek pada PT Siscom Technologies diperlukannya sebuah bahasa pemodelan untuk mendeskripsikan perancangan sistem. Bahasa pemodelan yang digunakan adalah UML (Unified Modelling Language) yang terdiri dari: Use Case Diagram, Activity Diagram, Sequence Diagram dan Class Diagram.

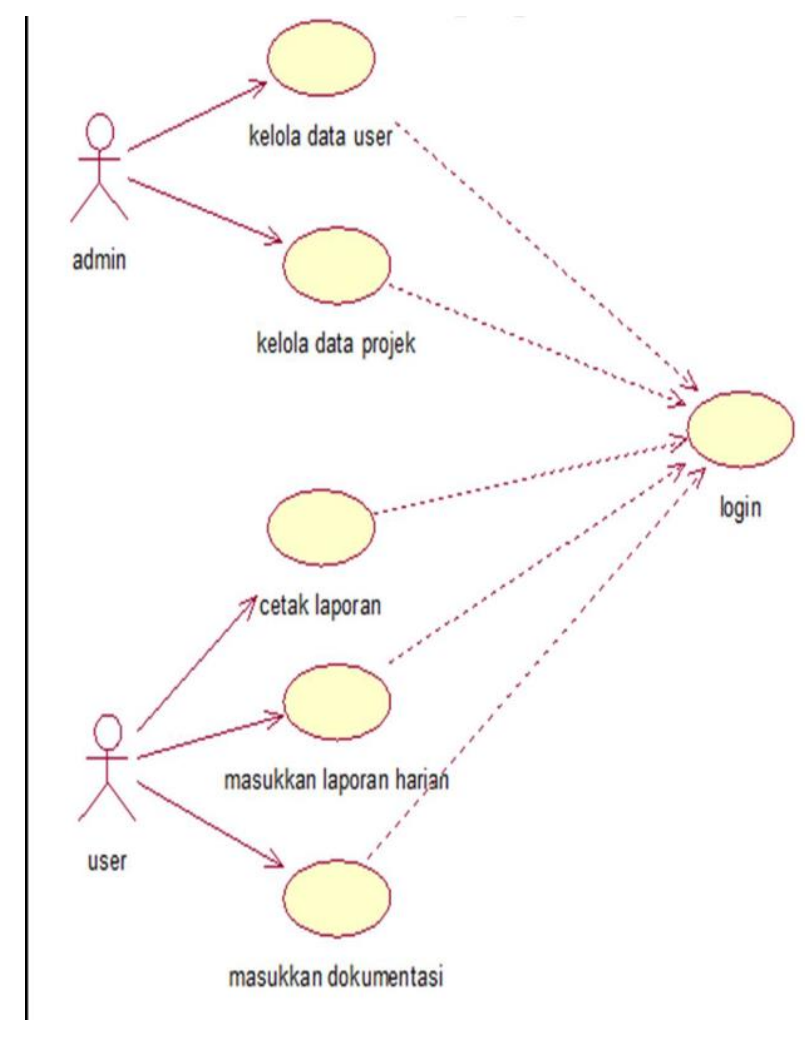

Gambar 1. Use Case Diagram 


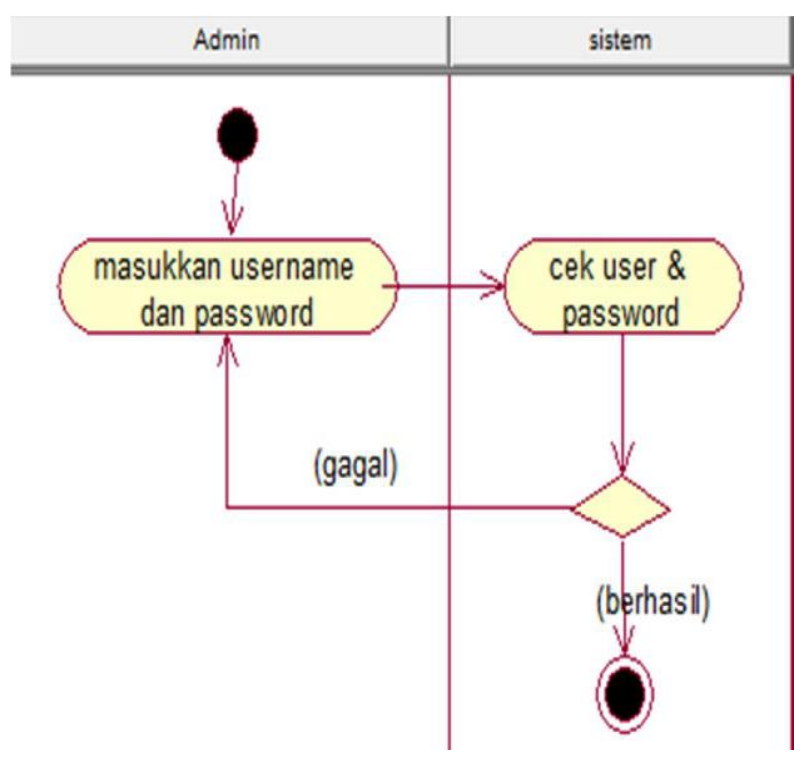

Gambar 2. Activity Diagram Login

Pada gambar 2 dijelaskan alur proses diketahui alur login. Dimana admin atau user memasukan username dan password, setelah user memasukan username dan password tersebut, maka sistem akan melakukan pengecekan terhadap akun ini, jika akun ini tersedia maka user akan berhasil masuk ke sistem ini dan jika akun yang dimasukkan tidak tersedia oleh sistem, maka sistem akan memberikan peringatan kepada user, bahwa akun yang dimasukkan salah.

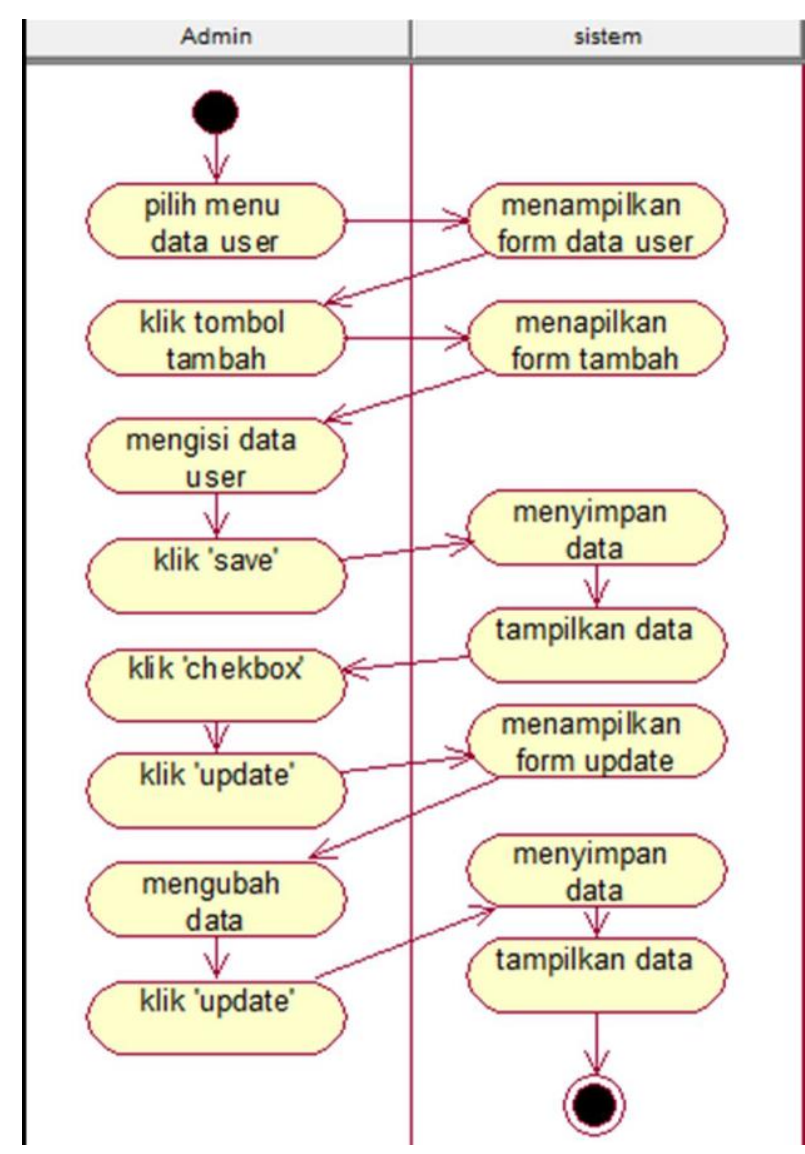

Gambar 3. Activity Diagram Kelola akun Karyawan

Dari gambar 3 dapat diketahui alur dari activity kelola data akun karyawan, user memilih menu user untuk manambah sebuah akun dan dalam activity ini yang berhak untuk mengelola menu user ini hanyalah Direktur atau Menejer yang akan menambah dan mengubah data akun. 


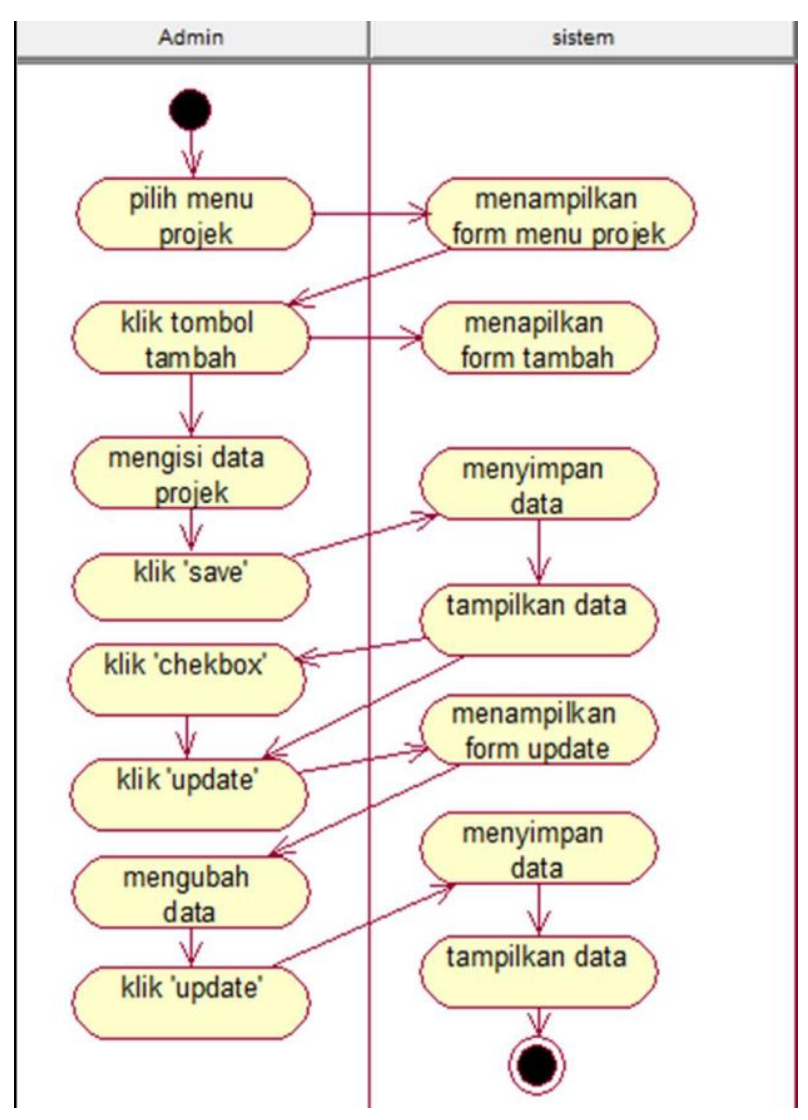

Gambar 4. Activity Diagram Kelola data Proyek

Dari gambar 4 dapat diketahui bagaimana user mengelola data sebuah proyek. User memilih menu proyek, maka akan muncul view semua proyek. Untuk menambah proyek, user diminta untuk klik tambah dan mengisi form tersebut. Setelah semua terisi, user diminta klik tombol save untuk menyimpan data sebuah proyek ke dalam sistem. Jika ada perubahan data identitas sebuah proyek, user diminta memilih terlebih dahulu proyek mana yang akan diubah identitasnya. Setelah dipilih klik tombol update akan muncul form yang berisikan data-data sebuah proyek. setelah identitas dirubah, user diminta untuk klik tombol save dan perubahan data akan di simpan dalam sistem.

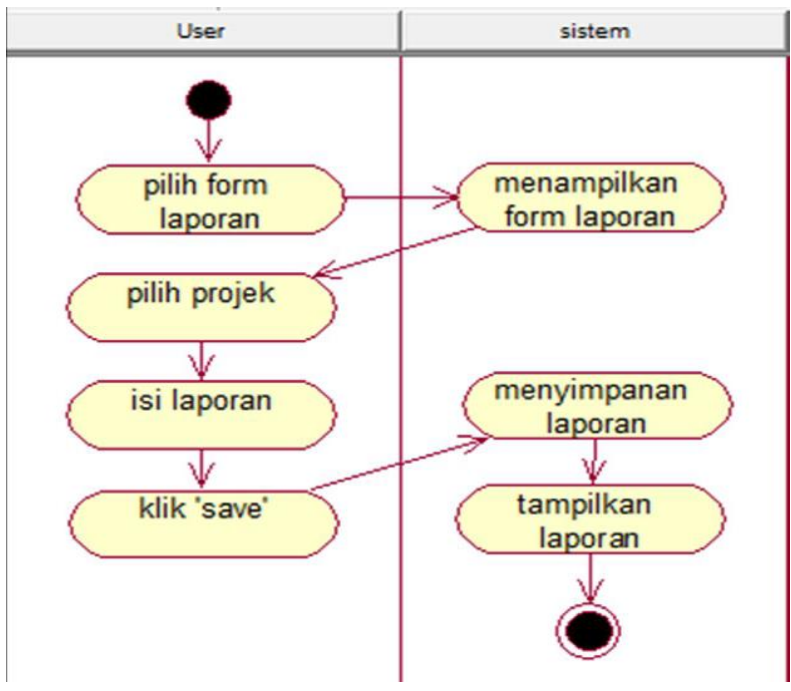

Gambar 5. Activity Diagram Isi Aktivitas Proyek

Dari gambar 5 diketahui bagaimana karyawan melaporkan aktivitasnya, diawali dengan memilih form laporan proyek setelah itu akan muncul form. Karyawan mengisi laporan tersebut. Sebelum itu karyawan terlebih dahulu memilih proyek mana yang akan dibuat laporannya. Setelah mengisi laporan aktivigas, klik save untuk menyimpan ke dalam sistem.

\section{HASIL DAN PEMBAHASAN}

Penelitian ini meliputi pembuatan Sistem Informasi Manajemen Pelaporan aktivitas harian proyek secara digital pada PT. Siscom Technologies. Semua data laporan dan pengolahan data tersimpan di database sehingga data tidak akan hilang dan memudahkan dalam pembuatan laporan.

Pada bagian ini dibahas hasil perancangan berupa sequence diagram, class diagram, Entity Relationship diagram, serta antar muka program berupa formulir input, dan menu. 


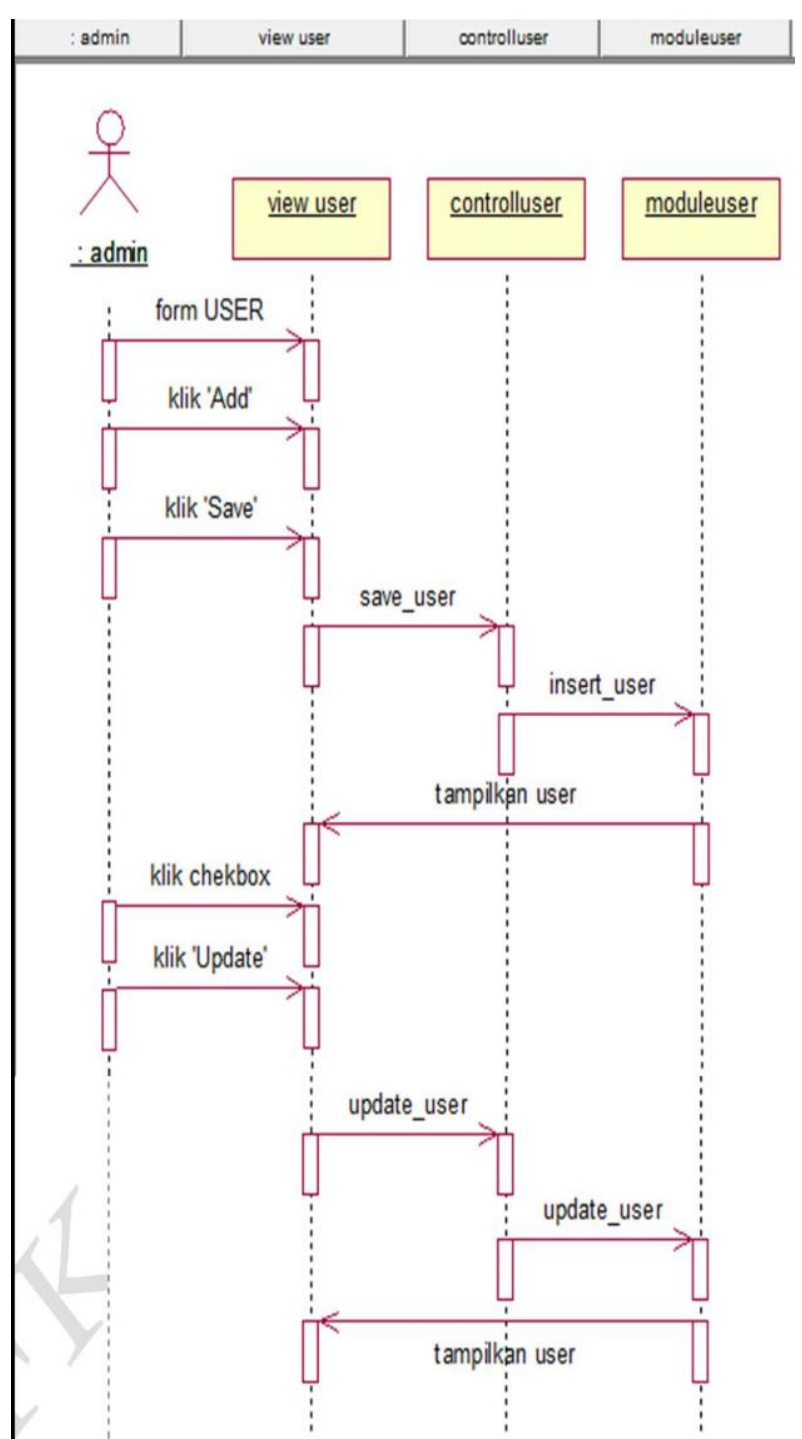

Gambar 6. Sequence Diagram kelola data akun user

Dari gambar 6 dapat dikeahui proses pengelolaan sistem akun. Setelah muncul form user oleh ViewUser. Klik tombol tambah dan akan muncul form untuk mengisi data-data user baru, setelah user klik save, maka control user akan melakukan operasi penyimpanan dan di akhiri oleh model user yang memberikan umpan balik yang ditampilkan oleh viewuser.

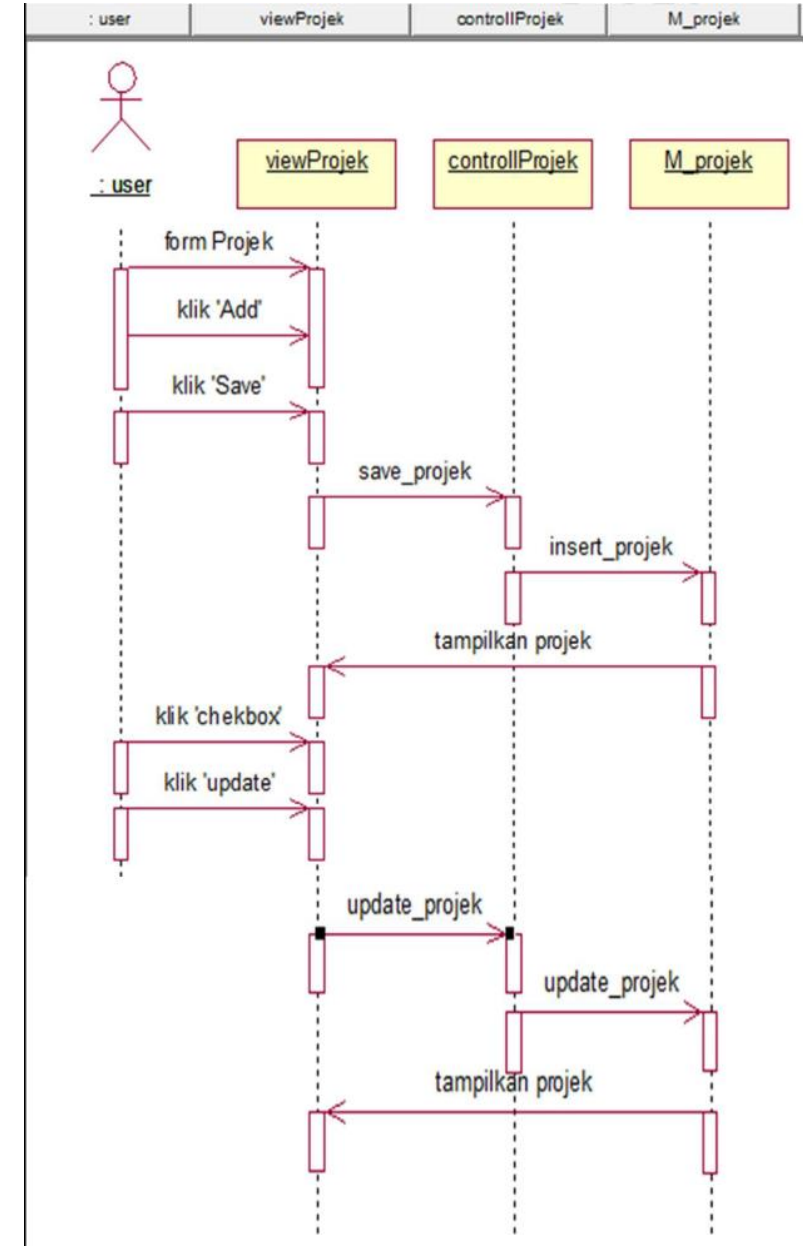

Gambar 7. Sequence Diagram kelola data Proyek

Dari gambar 7 diketahui dalam proses pengolaan data proyek, user klik tombol tambah di form proyek dan sistem akan menampilkan sebuah form input yang akan diisikan data-data sebuah proyek. Setelah mengisi semua data-data tersebut, user klik tombol save di form tersebut yang disediakan oleh viewprojek() dan dilanjutkan oleh contolprojek sebagai pengoperasian penyimpanan ke sistem. Setelah itu m_proyek bertindak sebagai media penyimpanan data-data proyek dan m_proyek juga akan menampilkan kembali data-data yang sudah dimasukan. 


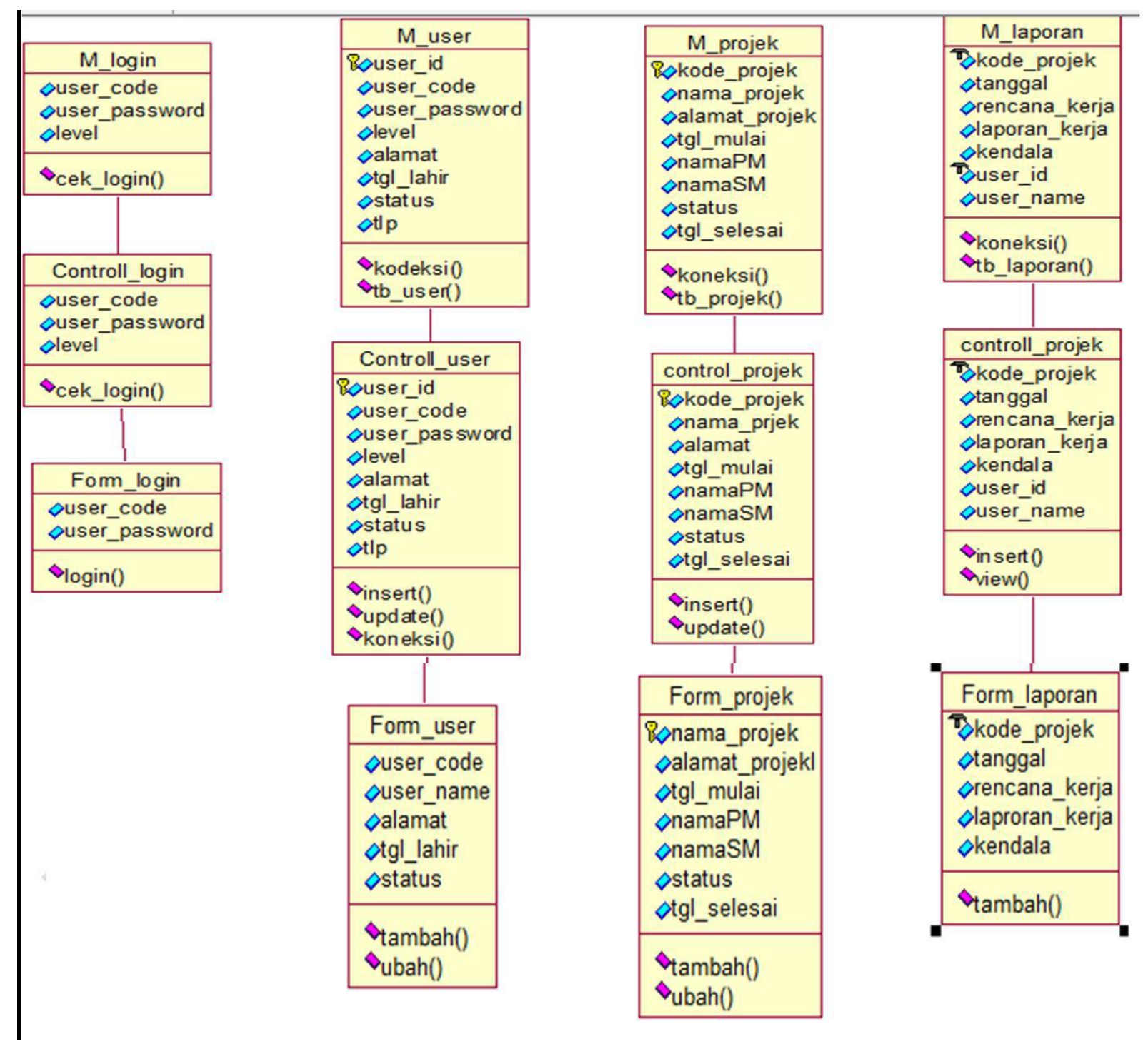

Gambar 8. Class Diagram 


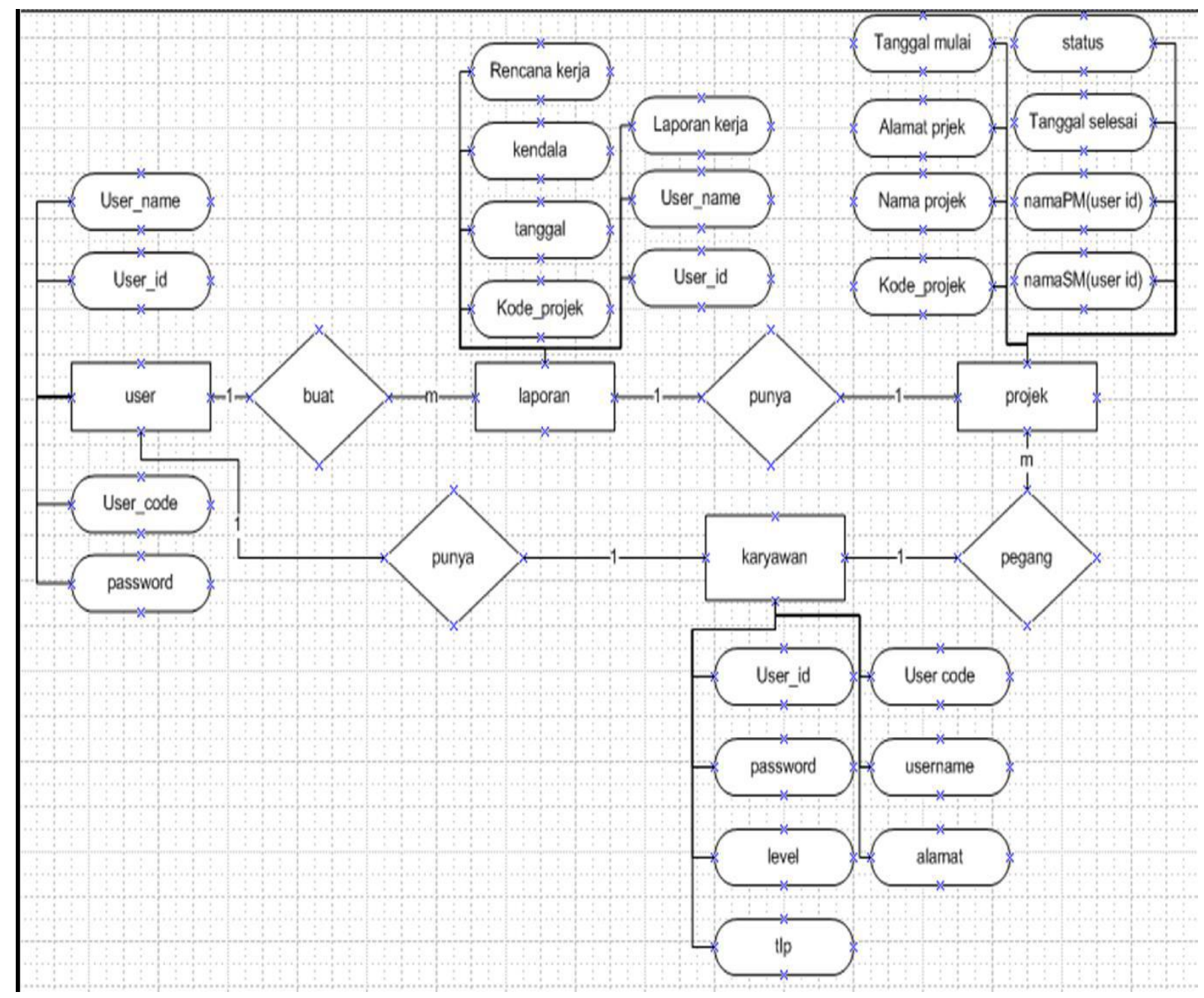

Gambar 9. Rancangan Entity Relationship Diagram

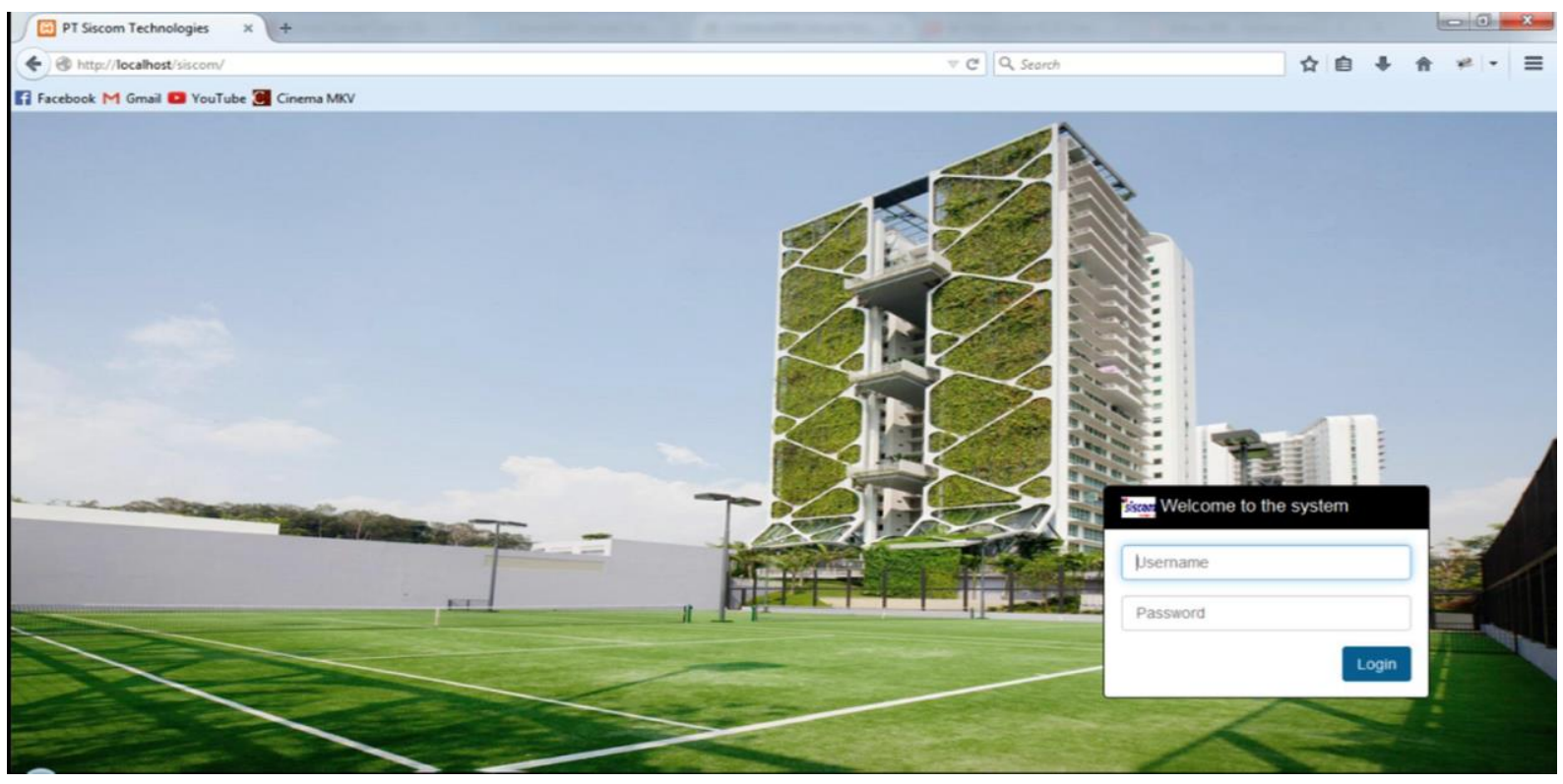

Gambar 10. Form Login 
Pada form login Gambar 10, tersedia field input Username dan Password.

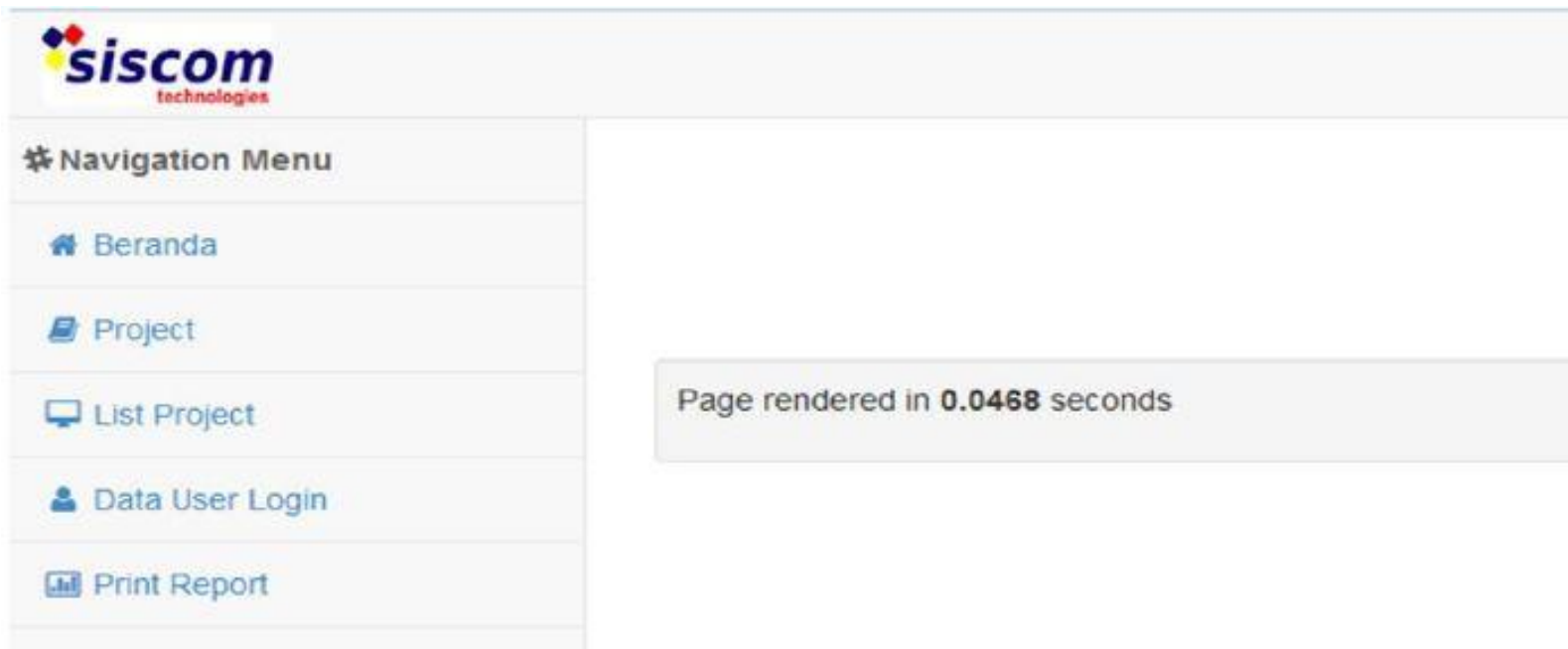

Gambar 11. Halaman Menu Utama

Dari gambar 11 dapat dilihat beberapa menu yang akan dioperasikan seperti : data user login, project, list project, cetak Laporan.

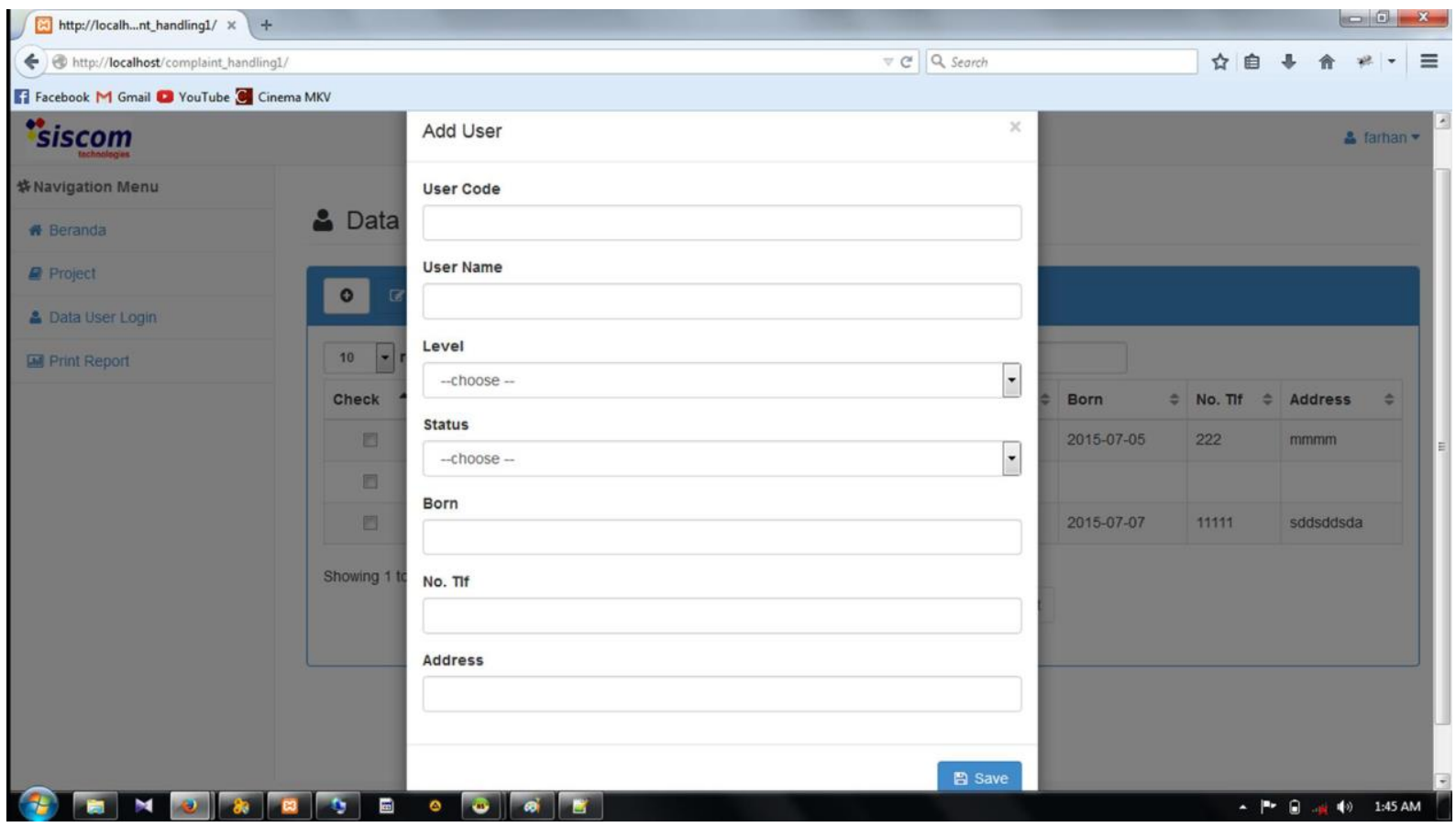

Gambar 12. Form Input data User

Dari gambar 12 dijelaskan setelah menekan tombol tambah akan muncul form yang akan diisi oleh user untuk mengisi data-data user baru 


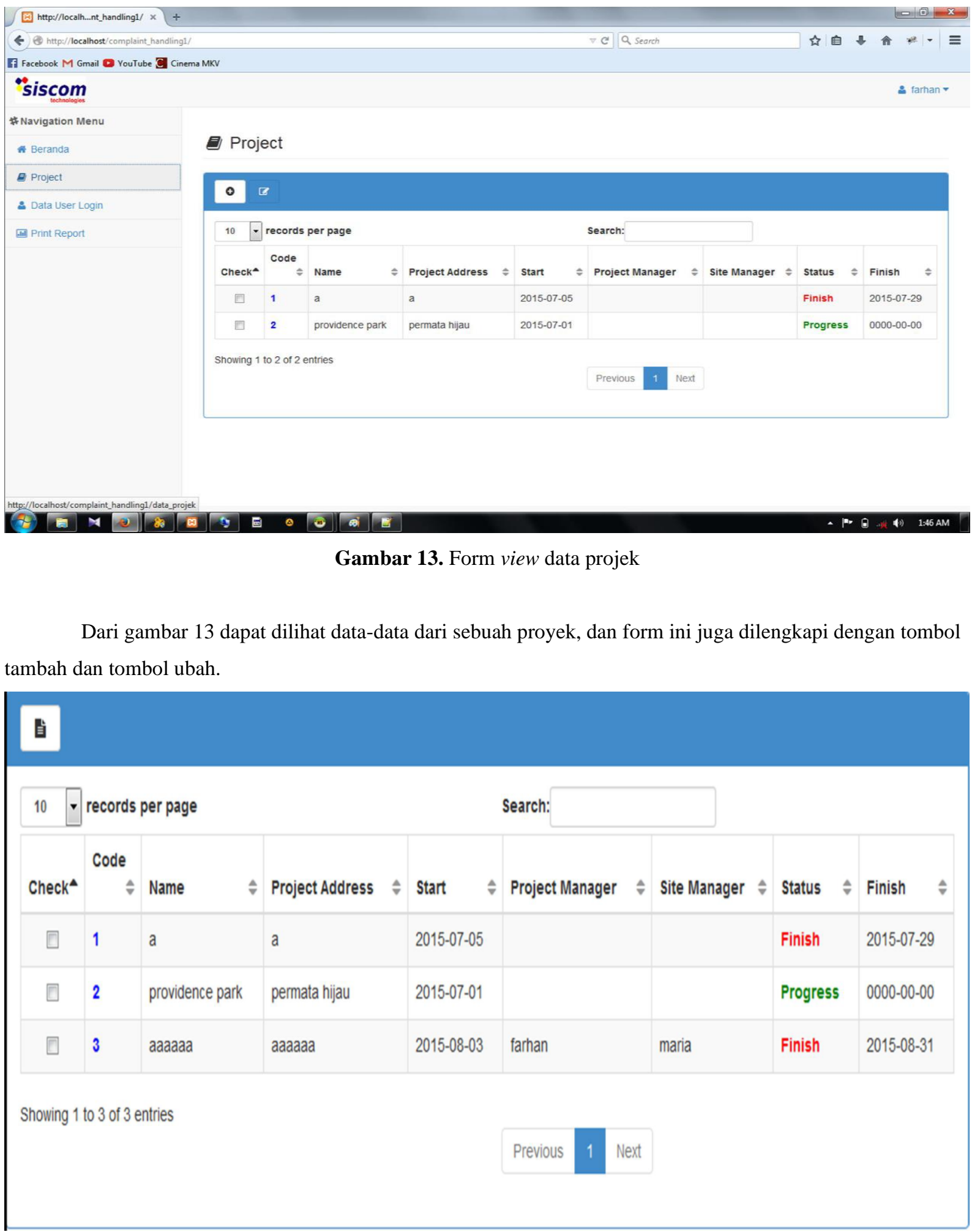

Gambar 14. Form view list projek

Dari gambar 14 menjelaskan tujuan form view list project ini adalah untuk melihat laporan yang sudah masuk ke dalam sistem ini, dengan cara memilih proyek dahulu dan menekan tombol view di bagian atas form. 


\section{冒 Detail Project}

\section{+ घ}

\begin{tabular}{|l|l|l|l|l|l|l|}
\hline \# & Date & Work Plan & Project Report & Obstecles & User ID & User Name \\
\hline 1 & $2015-08-02$ & $\begin{array}{l}\text { setting onu untuk lantai } 6 \\
\text { sampai } 10\end{array}$ & $\begin{array}{l}\text { onu sudah disetting semua, tapi tidak bisa } \\
\text { dipasang }\end{array}$ & ruangan semua dikunci & 20 \\
\hline 2 & $2015-08-03$ & pasang onu di lantai $6-10$ & onu yang terpasang di lantai $6-8$ & untuk lantai 9 dan 10 masih tetap & 20 & adib siraj \\
\hline
\end{tabular}

Gambar 15. Form view detail laporan projek

Dari gambar 15 dapat dilihat yakni detail dari laporan sebuah proyek. Sebelum user melihat ini terlebih dahulu memlih proyeknya yang sudah dijelaskan di gambar 14, setelah tekan tombol view, detail proyek akan ditampilkan seperti ini.

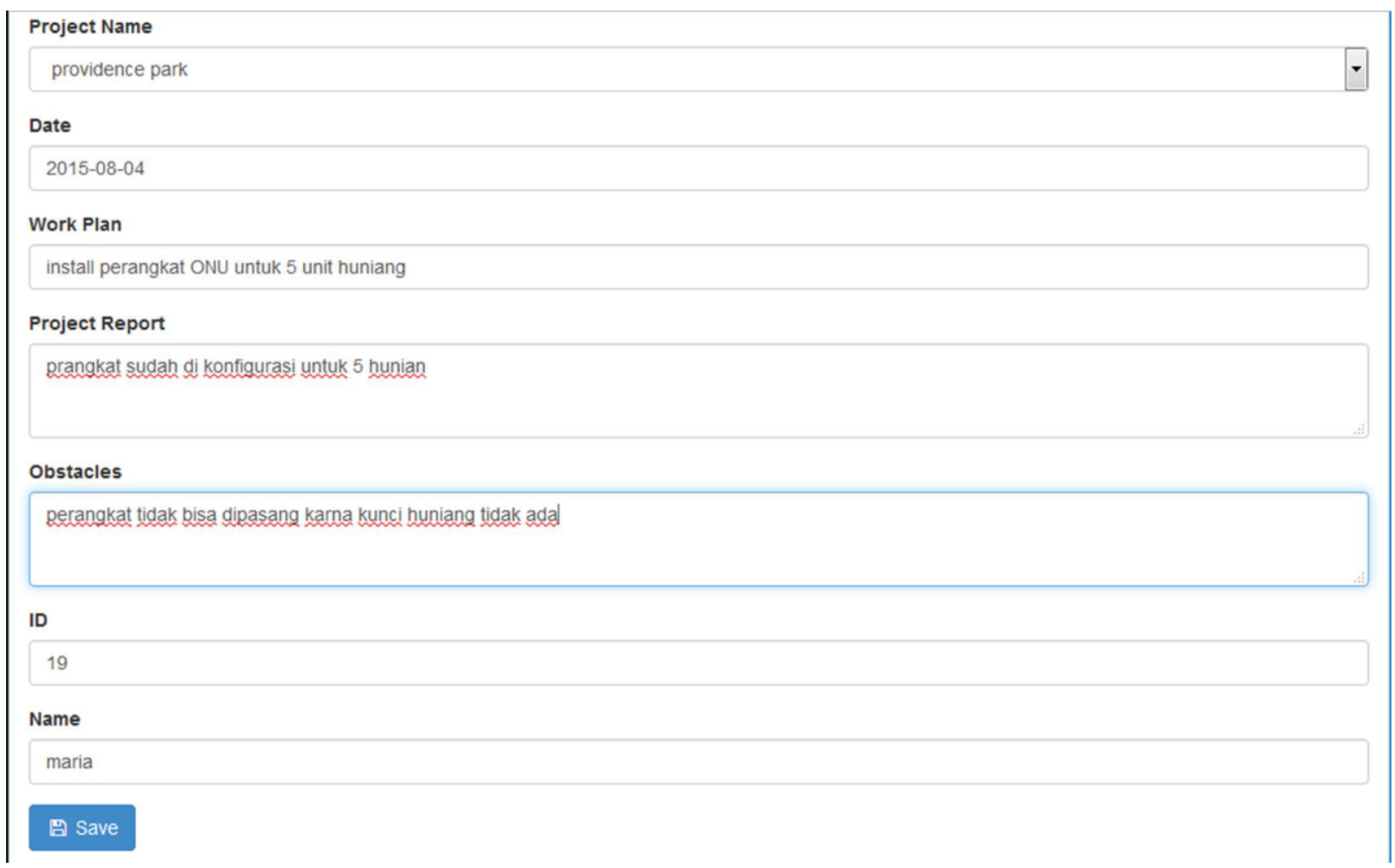

Gambar 16. Form Input Laporan Projek

Pada gambar 16 dijelaskan pengisian laporan proyek, diawali dengan memilih nama proyeknya, tanggal laporan, rencana kerja, laporan proyek, hambatam dalam kerja. Setelah itu nama atau user yang memasukkan laporan. 


\section{KESIMPULAN DAN REKOMENDASI}

Berdasarkan hasil analisa masalah yang terdapat pada bab 3, disimpulkan: Sistem berjalan dari pencatatan laporan aktivitas proyek pada Siscom dilakukan tanpa bantuan aplikasi. Hambatan sistem berjalan yakni terdapat ketidak teraturan dalam pelaporan. Salah satu akibatnya adalah hilangnya berkas laporan.

Dengan perancangan dan implementasi sistem informasi manajemen aktivitas harian proyek berbasis aplikasi web, mempermudah pegawai dalam mengirimkan laporan harian aktivitas proyek berdasarkan proyek yang dikerjakan. Direktur atau Project Manager dapat melihat laporan setiap proyek, dengan mudah.

Aplikasi berbasis web yang telah dikembangkan dapat mempermudah karyawan dalam pencatatan laporan proyek sampai pengirimannya. Hal ini dapat mempercepat proses pencatatan dan follow up setiap laporan pada PT Siscom Technologies secara efektif dan Efisien.

Adapun rekomendasi yang diberikan untuk memperbaiki sistem yang sudah berjalan selama ini di PT Siscom Technologies antara lain: Untuk mengurangi kesalahan dalam pencatatan laporan maka perlu dibuat suatu form dimana karyawan dapat mengisi laporan projek dengan cepat. Laporan yang sudah diinput dapat langsung tersimpan di database, sehingga mempermudah dalam pencarian data laporan.

Pengolahan data yang lama dapat diatasi dengan sistem yang terkomputerisasi dengan baik. Pembuatan kode yang bersifat unik untuk setiap proyek baru dapat mengurangi masalah redudancy data.

Perlu dilakukan pengujian yang lebih teliti supaya dapat memperbaiki kesalahan yang mungkin masih terdapat pada aplikasi yang telah dikembangkan.

\section{REFERENSI}

Huda, Miftakhul dan Bunafit. 2010. Membuat Aplikasi Database dengan Java, MySQL, dan NetBeans. Jakarta. Elex Media Komputindo.

Mulhim, Imam. 2013. Aplikasi Toko Bangunan Online dengan PHP dan MuSQL. Palembang. Setiawan, Rony. 2009. Teknik Pemecahan Masalah dengan ALGORITMA dan FLOWCHART. Lentera Ilmu. Jakarta.

Subhan, Mohamad. 2012. Analisa Perancangan Sistem. Lentera Ilmu Cendikia. Jakarta.

Sutabri, Tata. 2012. Analisis Sistem Informasi. CV Andi Offset. Yogyakarta.

Widianti, Sri. 2009. Pengantar Basis Data. Lentera Ilmu Cendikia. Jakarta.

Wu, C.Thomas. 2010. An Introduction To ObjectOriented Programming With Java ${ }^{\mathrm{TM}}$, Fifth Edition. McGraw-Hill. United States.

Widodo, Prabowo Pudjo dan Herlawati, 2011. Menggunakan UML (Unified Modeling Language). Informatika Bandung.

Yakub. 2012. Pengantar Sistem Informasi, Yogyakarta: Graha Ilmu.

Zakiyudin, Ais. 2012. Sistem Informasi Manajemen. Jakarta: Mitra Wacana Media. 